Shyshkin, V., Onyshchenko, O. and Cherniak, K. (2020), "Modern approaches to warehouse logistics management", Management and entrepreneurship: trends of development, Vol. 2, Issue 12, pp. 105-117, available at: https://doi.org/10.26661/2522-1566/2020-2/12-08

LOGISTICS AND SUPPLY CHAIN MANAGEMENT

\section{RECEIVED:}

25 March 2020

ACCEPTED:

28 April 2020

RELEASED:

20 July 2020
UDC 658.78 : 339.173

DOI $10.26661 / 2522-1566 / 2020-2 / 12-08$

\title{
MODERN APPROACHES TO WAREHOUSE LOGISTICS MANAGEMENT
}

\author{
Viktor Shyshkin \\ Zaporizhzhia National \\ University \\ Zaporizhzhia, Ukraine \\ ORCID ID: 0000-0001-8620-4722
}

\author{
Oksana Onyshchenko \\ Zaporizhzhia National \\ University \\ Zaporizhzhia, Ukraine \\ ORCID ID: 0000-0002-3009-3856
}

\author{
Kateryna Cherniak \\ Zaporizhzhia National \\ University \\ Zaporizhzhia, Ukraine \\ ORCID ID: 0000-0003-1742-6238
}

*Corresponding author email: oksana.onishchenko.znu@gmail.com

\begin{abstract}
The article aims to systematize the main approaches to the definition of warehouse concept. It analyses modern approaches to warehouse logistics management and identifies the main advantages and disadvantages of their use in the enterprise logistics system. In the article the theoretical aspects of warehouse logistics are revealed and the existing approaches to warehouse logistics management of modern enterprises are analysed. The mechanism of warehouse logistics management was explored as well as the ways to improve its efficiency were suggested. Methodology: general scientific theoretical and empirical methods of research as analysis and generalization, methods of observation and comparison, analytical, grouping of data were used. The urgency and expediency of warehouse modification at Ukrainian enterprises is substantiated. The relevance of the article is the need to adopt domestic enterprises to a qualitatively new system of economic relations and mechanisms of competitive relations of the modern market as well as the urgent necessity to adapt business entities to uncertainty in order to improve their management organization strategies, including warehouse logistics. The practical value of the research results is that the proposals and recommendations for improving the warehouse logistics management process identified in the paper can be used by enterprises in order to use modern innovative approaches to improving the quality of logistics processes. In addition, the implementation of the proposed provisions will significantly reduce the logistical costs of the enterprise and optimize the activities of any production company.
\end{abstract}

Keywords: warehouse, preservation of quality of goods, warehousing logistics, inventory, cost minimization, optimization of logistics processes, modern logistics approaches.

JEL Classification: D24, L23.

\section{INTRODUCTION}

In the face of fierce competition, the issue of efficient allocation of production resources and ensuring their optimum level with minimal costs is solved through the use of cutting-edge logistics tools that increase the competitiveness of the enterprise, integrating the entity into a single logistics chain. In turn, the functioning of the logistics chain will not be effective without its full integration into market requirements, and warehouse is the main link between the manufacturer and the consumer. Economic activity cannot be aimed at wasting potential, which is why it is important to 
qualitatively transform the actors of the market. To increase the level of economic activity, the company should minimize costs, including warehouse. In order to optimize such costs, there is warehouse logistics that helps in finding modern solutions for warehouse organization and process management in it.

\section{LITERATURE REVIEW}

International practice of business management indicates that the common way of increasing the competitiveness of enterprises in times of crisis is the logistic concept of management as businesses must organize their operations in such a way as to minimize the costs associated with moving and storing inventory from the primary source to the final consumer. One of the most important elements of the logistics management concept implemented at the enterprise is undoubtedly the optimization of its warehouse economy and ensuring the efficiency of warehouse logistics in general.

Theoretical issues of warehouse logistics management are covered in the works of Yu. K. Bazhenov et al. (1997), A. M. Hajinsky (2007), E. V. Krykavskyy (2004), R. Jindal (2012), I. A. Lenshin and Yu. I. Smolyakov (1996), H. Min (2006), Yu. M. Nerush and A. Yu. Nerush (2017), O. V. Tserkovna (2019), M. A. Oklander (2004), Y. V. Ponomariova (2003), B. Shah and V. Khanzode (2017), I. G. Smirnov (2004), T. Wild (2017) and others.

Nevertheless, the issues of qualitative organization and management of warehouse logistics at modern enterprises need more detailed study, given their significant actualization and role in forming the competitive advantages of the national economy.

\section{PAPER OBJECTIVE}

The purpose of the article is to systematize the main approaches to the definition of warehouse concept, to give examples of the basic systems of classification of warehouse space, to analyse the problems of existing approaches to warehouse logistics management of the enterprise and to reveal the advantages and disadvantages of the main modern areas of warehouse management in the domestic enterprise.

\section{METHODOLOGY}

Developing the research, general scientific theoretical and empirical methods were used, such as: analysis and generalization, methods of observation and comparison, analytical, grouping of data. The study also benefited from the Official State Statistics Committee of Ukraine's statistic data when researching the structure of the Ukrainian logistics services market.

\section{RESULTS AND DISCUSSION}

Warehousing logistics is a logistics industry that develops methods of organizing procurement, receiving, placement, accounting for material resources, warehousing and inventory management. The purpose of warehouse logistics is to reduce financial and time costs for warehousing and processing goods. Thus, warehouse logistics can be described as an open, stochastic, dynamic, sophisticated, and responsive feedback system that performs specific functions. The warehouse logistics system consists of several subsystems and functions to deliver goods to the full satisfaction of the buyer's needs with a minimum set cost level.

Enterprise storage system includes the following components: 
Shyshkin, V., Onyshchenko, O. and Cherniak, K. (2020), "Modern approaches to warehouse logistics management", Management and entrepreneurship: trends of development, Vol. 2, Issue 12, pp. 105-117, available at: https://doi.org/10.26661/2522-1566/2020-2/12-08

Table 1

Warehouse components

\begin{tabular}{cl}
\hline Warehouse component & \multicolumn{1}{c}{ Elements of warehouse component } \\
\hline Warehouse & Warehouse and warehouse territories \\
\hline Loading and unloading systems & $\begin{array}{l}\text { Loading and unloading equipment, car and rail } \\
\text { ramps }\end{array}$ \\
\hline Internal transport systems & Conveyors, forklifts, trolleys \\
\hline Goods processing systems & $\begin{array}{l}\text { Bar coding, sorting, packaging and packaging lines, } \\
\text { ordering }\end{array}$ \\
\hline Goods storage systems & $\begin{array}{l}\text { Shelves, pallets, containers, special equipment for } \\
\text { maintaining the quality of goods }\end{array}$ \\
\hline Systems of warehouse accounting of goods & $\begin{array}{l}\text { Manual, automated and computerized goods } \\
\text { accounting systems }\end{array}$ \\
\hline
\end{tabular}

\section{Source: own study}

Warehouse is an integral part of the activities of industrial enterprises, as its purpose is to reduce the time gap between production and consumption, which ensures the continuity of production and supply. Warehouse is a special building, construction and various equipment intended for receiving, placing and storing cargoes, preparing them for delivery to the consumer and consumption (Hadzhinsky, 2007).

When analyzing warehouse operations, it should be noted that they have certain features (mostly negative), such as:

1. Warehouses do not create additional consumer value, which means that warehouse operations are not a profitable activity.

2. The quality of cargo stored in a warehouse deteriorates over time and the risk of loss of goods as a result of theft increases.

3. Maintaining an appropriate warehouse and managing a warehouse requires considerable financial and time costs.

4. The long-term preservation of a large volume of stocks slows down the circulation of working capital (Ponomareva, 2003).

Logistics allows a complete and comprehensive analysis of any system of behavior in all its complexity and diversity, because the analysis of the operation of large systems requires a systematic approach. It can be concluded that a logistical approach is a systematic approach to the study of socio-economic systems. The peculiarity of the logistic approach is that each state of warehouse, as well as their totality is considered in relation, development and continuity and in the improvement to a qualitatively new state. Complex systems are thus regarded as a hierarchically interdependent set of open subsystems, and therefore, when making any management decision, their influence on related elements cannot be ignored (Grigor'ev and Uvarov, 2014).

The introduction of an efficient and technically equipped warehouse management at the enterprise on the basis of logistic approach allows achieving important production goals (Figure 1): 


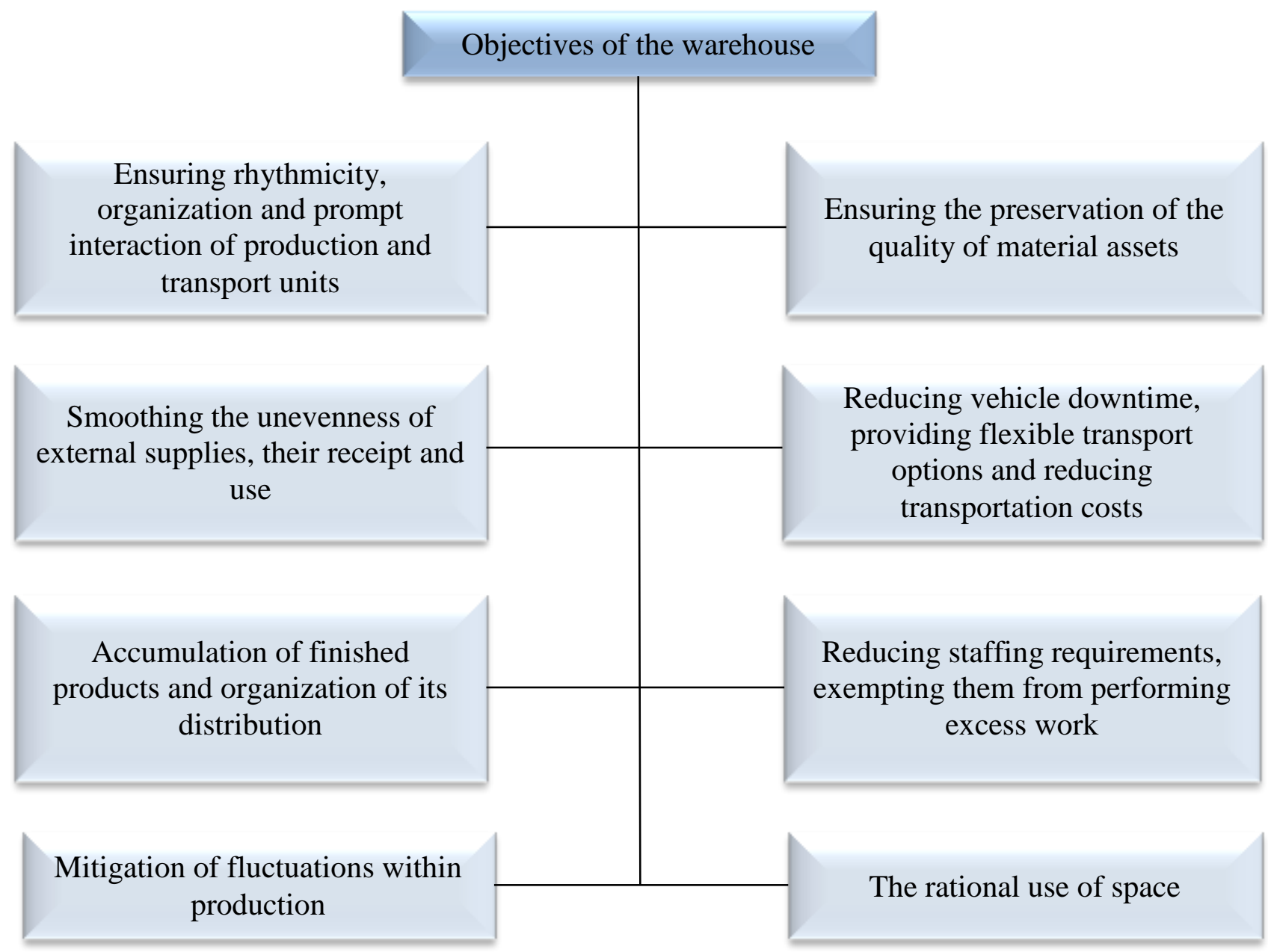

Figure 1. The main goals of creating a warehouse

\section{Source: own compilation}

So, analysing the goals of the warehouse management, the main tasks of warehouse logistics are the following:

1) placement of the warehouse network at the landfill;

2) effective inventory management;

3) storage and preparation of goods for delivery;

4) organization of deliveries and unloading and loading works.

The main purpose of warehousing in the enterprise logistics system is not to store goods, but rather to transform the parameters of material flows in order to use them as efficiently as possible. Such parameters are the volumes and quantitative composition of the consignments of goods, the method and type of packing, the number of nomenclature in the consignments, the time of departure and arrival of the consignments, etc.

It is at the level of the logistics chain that the main functions and technical requirements for the warehouse economy of the enterprise are formed. Therefore, in order to achieve a high level of warehouse operations and increase the level of profitability of the business, it is necessary to consider warehouses as an integrated component of the logistics chain. The profitability of the warehouse system of an enterprise is achieved only by an individual approach to its creation, taking into account all factors of influence. To accomplish these tasks, it is necessary to specifically define the functional tasks of the storage system. 
Shyshkin, V., Onyshchenko, O. and Cherniak, K. (2020), "Modern approaches to warehouse logistics management", Management and entrepreneurship: trends of development, Vol. 2, Issue 12, pp. 105-117, available at: https://doi.org/10.26661/2522-1566/2020-2/12-08

Therefore, most scientists focus on the four basic functions of warehousing:

- transformation of production process into consumer according to demand;

- storage;

- transportation and unification of cargo;

- information support of warehouses and control over the process of order fulfillment;

- operations to maintain a high level of customer service.

In modern theory and practice, there are a large number of classifications of warehouses, which may be presented, according to their specific features in table 2:

The main types of warehouses

\section{Classification mark}

Functional purpose
Sorting-distributive, cumulative and transittransshipment

small - up to 5 thousand $\mathrm{m}^{2}$, up to 1 thousand tons; average - from 5 to 10 thousand $\mathrm{m}^{2}$, from 1 to 6 thousand tons;

Size of usable storage area (storage volume) large - more than 10 thousand $\mathrm{m}^{2}$, more than 6 thousand tons

The level of automation and mechanization of unloading and loading operations

Non-mechanized, mechanized, complex-mechanized, automated and automatic

Transportation conditions

Ritual, at marinas, port, non-run (inland)

Individual use, sharing
Ownership

Surface height of premises

Temperature mode
Public, collective, private, joint

The technical structure that determines the mode of storage of goods

Low-altitude (single-storey), mid-altitude, high-altitude

Attitude towards logistics intermediaries

Own warehouses, warehouses of logistics intermediaries

Relation to the basic areas of logistics

Supply warehouses, distribution warehouses, production warehouses

The kind of products stored in the warehouse

Warm, heated, unheated, refrigerated warehouses

General merchandise, special

Warehouses of raw materials, components, materials, warehouses of work in progress, warehouses of containers, warehouses of return waste, warehouses of finished goods 
Thus, sorting-distributive warehouses make a big share in the warehouse turnover. Such warehouses are built for logistical operations on acceptance of cargo from the supplier, sorting, picking of cargo according to the order of retail resellers. Usually, they focus on current inventory, which does not last long. Such a function as cargo storage for sorting warehouses is not typical.

Transit and transshipment warehouses are created for the purpose of transporting goods from the production areas to the points of consumption by different modes of transport. Such warehouses act as transshipment points, which provide unloading of the goods that arrived on one mode of transport, its reception and sorting according to the destination and loading on another mode of transport.

Cumulative warehouses are created at the enterprise for the purpose of seasonal and long-term storage of goods. Warehouses ensure the long-term storage of cargo, so an important role is played by a quality control of cargo storage function in that case. Cumulative warehouses are concentrated mainly in the wholesale trade. Together with the main function of accumulation and storage of cargo, such warehouses carry out auxiliary technological operations related to the acceptance and dispatch of goods to wholesale intermediaries.

To characterize the Ukrainian segment of warehouse real estate, it should be noted that it consists of objects of the following types:

1) warehouses located in the territory of existing enterprises or those that are idle;

2) warehouses belonging to transport and forwarding companies;

3) repurposed industrial objects;

4) unfinished construction works being already completed;

5) basement and basement floors of buildings.

Only $15 \%$ of the Ukrainian warehousing segment is professionally designed and equipped with warehouse terminals and logistic complexes built at the end of the twentieth century.

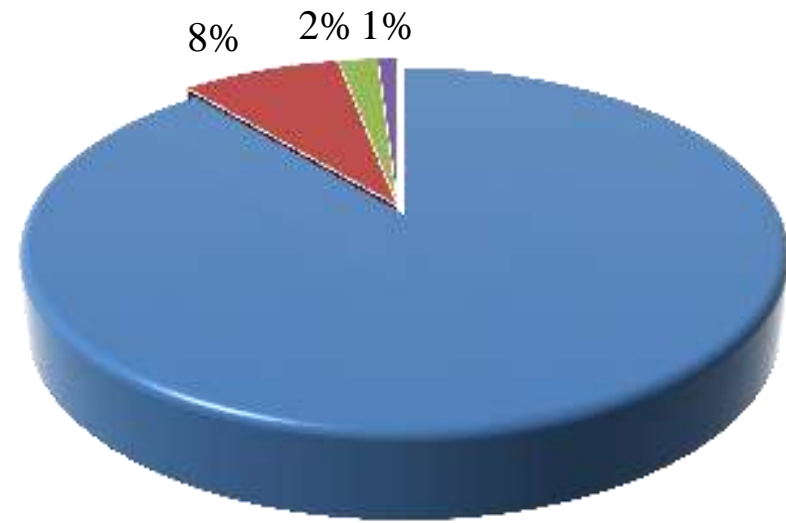

$89 \%$

Transport $"$ Storage $\backsim$ Forwarding $"$ Supply Chain Management

Figure 2. Structure of the Ukrainian logistics services market, 2018

Source: modified after (Official State Statistics Committee of Ukraine, 2020)

According to the results of the research (Official State Statistics Committee of Ukraine, 2020), the Ukrainian market of logistics services has the following structure: transport - $89 \%$, storage $-8 \%$, freight forwarding $-2 \%$, management of logistics supply chains $-1 \%$ (Figure 2). In addition, experts predict the stabilization of the Ukrainian logistics market with a further growth rate of 6 to $9 \%$ over the next 3-5 years. 
Shyshkin, V., Onyshchenko, O. and Cherniak, K. (2020), "Modern approaches to warehouse logistics management", Management and entrepreneurship: trends of development, Vol. 2, Issue 12, pp. 105-117, available at: https://doi.org/10.26661/2522-1566/2020-2/12-08

The modern state approach of solving the problem of Ukrainian logistics is not able to effectively control the market of logistics services. There is no specialist training base in Ukraine, as well as training centers for such specialists. The implementation of modern logistics management approaches is constantly hampered by the state's inability to assimilate and integrate new ideas. For example, due to the imperfection of the legal framework, Ukraine still cannot resolve the issue of introduction and use of electronic document flow. Adoption of the relevant laws would improve the quality of logistics services, accelerate cash flow, process documents and currency transactions, which will give more opportunities to domestic players in the logistics services market to compete in foreign markets.

In the process of economic activity, the industrial enterprise faces the question of modifying warehouse activity, assessing the feasibility of existing ways of providing the company with warehouse space and the optimal search for ways to provide themselves with storage facilities or increase the efficiency of use in the presence of their own.

Modern logistic approaches are characterized by the emergence of a new concept of efficient management of logistics processes and business in general, which aims at reducing the time and financial costs associated with freight in the logistics chain. Supply Chain Management is called logistics supply chain management, through the integration of all business processes that underlie logistics. The basis of these popular modern methods of production modification is warehousing logistics.

At the present stage of development of domestic logistics, several trends can be traced that determine the importance of logistics in the effective construction of business processes:

1. Expanding the opportunity to increase the level of profitability of the business by minimizing production costs and reducing turnover costs.

2. Development of IT technologies and modification of information flows.

3. Active search for the most effective forms of organization of interaction of all market participants.

4. The need to regulate the processes of goods movement not only at the enterprise scale, but also at the regional and national level.

5. Improvement of technology (the logistics system is developing due to modern technical achievements in the transport and storage economy) (Miahkov, 2016).

The development of the warehouse industry in Ukraine is accompanied by a number of obstacles, such as:

1. Lack of land for storage facilities.

2. The complexity of the process of land lease registration.

3. Underestimation of economic benefits by local authorities for the region's extensive warehouse facilities.

4. The unwillingness of domestic companies to invest in warehouse automation.

Today in the domestic market there is a fierce competition between suppliers of different types of products, and the ever-increasing demands on the level of logistic service, speed of supply and quality of products require the majority of enterprises to invest more forces and means for improving the efficiency of supply chain management. Most SMEs successfully minimize costs and strengthen their competitive position by using modern approaches to warehouse management. Consequently, at some stage the idea of cross-docking emerged.

Cross-docking is the process of receiving and sending goods directly through a warehouse, that is, without placing them in a long-term storage area. Such a modern logistical approach involves unloading goods from incoming vehicles and loading them directly into the leaving trucks, eliminating the storage function between these processes. Cross-docking can be used to change the type of transportation, sorting of cargo destined for different destinations, grouping groupage loads from different sources into one container or vehicle. Such a logistic approach is a set of logistics operations in the middle of the supply chain that allow you to ship out of stock and deliver goods with a minimum delivery time. 
Cross-docking is divided into two directions:

1) one-stage, when the cargo passes through the warehouse as a single order;

2) two-stage, for which the shipped goods are re-consigned, with the goods in storage are grouped or vice versa.

Cross-docking eliminates the costs of cargo storage, reduces the need for storage space and staff, and the receiving organization minimizes delivery time to the end consumer and the cost-effectiveness of deliveries, as well as extends customer base geography. According to the latest scientific research, the introduction of the cross-docking approach allows to minimize logistical costs for the delivery of goods from 5 to $15 \%$. However, the use of cross-docking is impossible in the absence of counterparties, which is the basis of this method. Thus, potential partners may not have the necessary storage facilities or cargo fleet to operate the cross-docking system. It is critically important for a logistics company that uses cross-docking to have an appropriate IT system to monitor the execution of logistics operations and track the movement of goods. When transporting fragile loads, additional processing of the goods increases the risk of damage to the cargo (Table 3 ).

Table 3

Advantages and disadvantages of using cross-docking

Advantages

Exclusion of costs related to storage of cargo

Reducing the need for storage space

Minimize delivery time to the end consumer

Expanding the geography of the client base

\section{Disadvantages}

Subcontractors are required

Cargo or transport fleet storage options are required

Availability of IT system for controlling the execution of logistics operations

Risk of damage to fragile loads if they are further processed

\section{Source: own compilation}

One of the key principles of warehouse logistics is the analysis of existing management decisions to find ways to improve their efficiency. Based on this principle, there are modern approaches to optimizing logistics processes in warehouses:

1) "just in time" system, characterized by the fact that it clearly defines the exact time, amount of materials and the end result, which allows to optimize flows in such a way as to minimize production volumes;

2) ordering, which includes several systems of technological operations:

2.1 automated system, managed by the operator and allows you to automatically submit goods;

2.2 reducing the total time of order collection by eliminating downtime. This is due to the compilation of a route map detailing the way of movement of the collector, which in turn shortens the delivery time by almost half;

2.3 logistic coordination between retailers and wholesalers to improve the promotion of finished goods;

3) a system for scheduling resource requirements that minimizes inventory and storage costs (Krykavskyy, 2004). 
Shyshkin, V., Onyshchenko, O. and Cherniak, K. (2020), "Modern approaches to warehouse logistics management", Management and entrepreneurship: trends of development, Vol. 2, Issue 12, pp. 105-117, available at: https://doi.org/10.26661/2522-1566/2020-2/12-08

\section{CONCLUSION}

In the process of economic activity, the industrial enterprise faces the challenge of modifying warehouse activity, assessing the feasibility of existing ways of providing the enterprise with warehouse space and the optimal search for ways of securing itself with storage facilities or improving the efficiency of use in the presence of their own.

At the present stage of development of domestic logistics, several trends can be traced that determine the importance of logistics in the effective construction of business processes:

1. Expanding the opportunity to increase the level of profitability of the business by minimizing production costs and reducing turnover costs.

2. Development of IT technologies and modification of information flows.

3. Active search for the most effective forms of organization of interaction of all market participants (manufacturers, consumers, intermediaries, transport, warehouses).

4. The need to regulate the processes of goods movement not only at the enterprise scale, but also at the regional and national level.

5. Improvement of equipment (the logistics system is developing due to modern technical achievements in the transport and storage economy).

The development of the warehouse industry may be accompanied by a number of obstacles, such as:

1. Lack of land for storage facilities.

2. The complexity of the process of land lease registration.

3. Underestimation of economic benefits by local authorities for the region's extensive warehouse facilities.

4. The companies' unwillingness to invest in warehouse automation.

5. Absence of a base of specialists with appropriate professional training, as well as centers of training of such specialists.

6. Retarding the implementation of modern logistics management approaches due to the state's inability to assimilate and integrate new ideas.

7. The imperfection of the legislative framework, which is why some countries still cannot resolve the issue of introduction and use of electronic document circulation.

To solve the current problems of warehousing logistics, most large and medium-sized companies successfully minimize costs and strengthen their competitive position, using modern approaches to warehouse management, among which are the following:

1) introducing cross-docking methods, i.e. receiving and sending goods directly through the warehouse, i.e. without placing them in a long-term storage area;

2) application of the "just in time" system, which allows to optimize processes at warehouses;

3) warehouse management automation and use of modern IT technologies;

4) the use of a resource needs planning system that minimizes inventory and storage costs;

5) the application of the Supply Chain Management concept to manage logistics supply chains by integrating all business processes that underlie logistics;

6) ordering, which includes several systems.

The application of modern approaches in the management of warehousing logistics will allow companies to reasonably and purposefully resolve the issue of optimization of logistics operations in the supply chain, to implement the transition to innovative methods and technologies that correspond to the period of formation of the market of logistics services. 


\section{REFERENCES}

Ding, S. and Kaminsky, P. M. (2019), "Centralized and Decentralized Warehouse Logistics Collaboration", Manufacturing \& Service Operations Management, available at: http://dx.doi.org/10.1287/msom.2019.0774 (Accessed 6 January 2020), DOI: $10.1287 / \mathrm{msom} .2019 .0774$

Grigor'ev, M. N. and Uvarov, S. A. (2014), Logistika [Logistics]. JURAJT, Moscow (in Russian). Hadzhinsky, A. M. (2007), Logistika [Logistics]. Data center "Marketing", Moscow (in Russian). Jindal, R. (2012), "Comparative Study of Data Warehouse Design Approaches: A Survey", International Journal of Database Management Systems, Vol. 4(1), pp.33-45, available at: http://dx.doi.org/10.5121/ijdms.2012.4104 (Accessed 6 January 2020), DOI: 10.5121/ijdms.2012.4104

Krykavskyy, E. V. (2004), Lohistyka. Dlia ekonomistiv [Logistics. For Economists]. Publishing House of the National University "Lviv Polytechnic", Lviv, (in Ukrainian).

Lenshin, I.A. and Smolyakov, Yu. I. (1996), Logistika [Logistics]. Mechanical Engineering. Moscow, (in Russian).

Miahkov, A. (2016), "Warehouse logistics and cross-docking - 15\% savings", Agropolit.com (online platform), available at: https://agropolit.com/spetsproekty/151-skladska-logistika-takros-doking---15-ekonomiyi (Accessed 1 February 2020), (in Ukrainian).

Min, H. (2006), "The applications of warehouse management systems: an exploratory study", International Journal of Logistics Research and Applications, Vol. 9(2), pp.111-126, available at: http://dx.doi.org/10.1080/13675560600661870 (Accessed 7 January 2020), DOI: 10.1080/13675560600661870

Nerush, Yu. M. and Nerush, A. Yu. (2017), Lohistyka [Logistics]. Izdatel'stvo Jurajt, Moscow, available at: https://www.biblio-online.ru/bcode/388073 (Accessed 5 February 2020), (in Russian).

Official State Statistics Committee of Ukraine, (2020), Available at: http://www.ukrstat.gov.ua/ (Accessed 5 February 2020), (In Ukrainian).

Oklander, M. A. et al. (2004), Promyslova lohistyka [Industrial Logistics] Center of Educational Literature, Kiev, (in Ukrainian).

Pattison, I. (1988), "System trends in warehouse management", Logistics World, Vol. 1(2), pp.6568, available at: http://dx.doi.org/10.1108/eb007418 (Accessed 5 February 2020), DOI: 10.1108/eb007418

Ponomareva, Yu. V. (2003), Lohistyka. [Logistics]. Center of Educational Literature Kiev, (in Ukrainian).

Shah, B. and Khanzode, V. (2017), "A comprehensive review of warehouse operational issues", International Journal of Logistics Systems and Management, Vol. 26 (3), p.346, available at: http://dx.doi.org/10.1504/ijlsm.2017.081962 (Accessed 10 January 2020), DOI: 10.1504/ij1sm.2017.081962

Smirnov, I.G. (2004), Lohistyka: prostorovo-terytorial'nyj vymir [Logistics: spatial-territorial dimension]. BGL Horizons, Kiev (in Ukrainian).

TBN WORLD WIDE LOGISTIKS. What is Cross Docking? Available at: https://tbncom.com/publ/automobilnye_perevozki_road_transport/sbornye_gruzy/chto_takoe_ kross_doking/15-1-0-303 (Accessed 20 December 2019), (in Russian).

Toomey, J.W. (2000), “Inventory Management Organization”, Inventory Management, pp.195-208, available at: http://dx.doi.org/10.1007/978-1-4615-4363-3_14 (Accessed 14 January 2020), DOI: $10.1007 / 978-1-4615-4363-3 \_14$

Tserkovna, O. V. (2019), "Theoretical and methodical approaches to innovational logistics in industry", Market economy: modern management theory and practice, Vol. 18 1(41), pp. 224- 
Shyshkin, V., Onyshchenko, O. and Cherniak, K. (2020), "Modern approaches to warehouse logistics management", Management and entrepreneurship: trends of development, Vol. 2, Issue 12, pp. 105-117, available at: https://doi.org/10.26661/2522-1566/2020-2/12-08

235, available at: http://dx.doi.org/10.18524/2413-9998.2019.1(41).173806 (Accessed 5

February 2020), (in Ukrainian), DOI: 10.18524/2413-9998.2019.1(41).173806

Ukrainian branch magazine "Distribution and Logistics", available at: https://ukrlogistica.com.ua (Accessed February 2020).

Wild, T. (2017), "Supply chain inventory management", Best Practice in Inventory Management, pp. 217-237, available at: http://dx.doi.org/10.4324/9781315231532-16 (Accessed 5 February 2020), DOI: $10.4324 / 9781315231532-16$

\section{СПИСОК ВИКОРИСТАНИХ ДЖЕРЕЛ}

Ding, S. and Kaminsky, P.M. Centralized and Decentralized Warehouse Logistics Collaboration, Manufacturing \& Service Operations Management. 2019. URL: http://dx.doi.org/10.1287/msom.2019.0774 (дата звернення: 6.01.2020).

Григорьев М. Н., Уваров С. А. Логистика. 4-е изд., испр. и доп. Москва : Издательство Юрайт, 2014. 836 с.

Гаджинский А. М. Логистика. Москва : ИОЦ «Маркетинг», 2007. 256 с.

Jindal, R. Comparative Study of Data Warehouse Design Approaches: A Survey. International Journal of Database Management Systems. 2012. 4(1), pp.33-45. URL: http://dx.doi.org/10.5121/ijdms.2012.4104 (дата звернення: 6.01.2020).

Крикавський Є.В. Логістика. Для економістів. Львів : Видавництво Національного університету «Львівська політехніка», 2004. 448 с.

Леншин И. А., Смоляков Ю. И. Логистика. В 2 ч. : Ч. 1. Москва : Машиностроение, 1996. $246 \mathrm{c}$.

Мягков А. Складська логістика та крос-докінг - 15\% економії. Онлайн-платформа «Agropolit.com» URL: https://agropolit.com/spetsproekty/151-skladska-logistika-ta-krosdoking---15-ekonomiyi (дата звернення: 1.02.2020)

Min, H. The applications of warehouse management systems: an exploratory study. International Journal of Logistics Research and Applications. 2006. 9(2), pp.111-126. URL: http://dx.doi.org/10.1080/13675560600661870 (дата звернення: 5.01.2020).

Неруш, Ю. М., Неруш А.Ю. Логистика. 5-е изд., перераб. и доп. Москва: Издательство Юрайт, 2017. 559 c. URL: https://www.biblio-online.ru/bcode/388073 (дата звернення: 5.02.2020).

Офіційний сайт Державного комітету статистики України. URL: http://www.ukrstat.gov.ua/ (дата звернення: 5.02.2020).

Окландер М. А. та ін. Промислова логістика. Київ : Центр навчальної літератури, 2004. 222 с.

Pattison, I. (1988). "System trends in warehouse management", Logistics World, 1(2), pp.65-68. URL: http://dx.doi.org/10.1108/eb007418 (дата звернення: 5.02.2020).

Пономарьова Ю. В. Логістика. Київ : Центр навчальної літератури, 2003. 192 с.

Shah, B. and Khanzode, V. A comprehensive review of warehouse operational issues. International Journal of Logistics Systems and Management. 2017. 26 (3), p. 346. URL: http://dx.doi.org/10.1504/ijlsm.2017.081962 (дата звернення: 10.01.2020).

Смирнов І. Г. Логістика: просторово-територіальний вимір : монографія. Київ : ВГЛ Обрії, 2004. $335 \mathrm{c}$.

TBN WORLD WIDE LOGISTIKS. Что такое Кросс-докинг? URL: https://tbncom.com/publ/automobilnye_perevozki_road_transport/sbornye_gruzy/chto_takoe_ kross_doking/15-1-0-303 (дата звернення: 20.12.2020).

Toomey, J.W. Inventory Management Organization. Inventory Management. 2000. pp.195-208. URL: http://dx.doi.org/10.1007/978-1-4615-4363-3_14 (дата звернення: 14.01.2020).

Церковна А. В. Теоретико-методичні підходи до інноваційної логістики у промисловості. Ринкова економіка: сучасна теорія і практика управління. 2019. Т. 18, вип. 1. С. 224235. 
Український галузевий журнал «Дистрибуция и логистика». URL: https://ukrlogistica.com.ua (дата звернення: 15.02.2020)

Wild, T. Supply chain inventory management. Best Practice in Inventory Management. 2017. pp.217-237. URL: http://dx.doi.org/10.4324/9781315231532-16 (дата звернення: 5.02.2020).

\section{СУЧАСНІ ПІДХОДИ ДО УПРАВЛІННЯ СКЛАДСЬКОЮ ЛОГІСТИКОЮ}

\section{Шишкін Віктор}

Олександрович

Запорізький національний університет

м. Запоріжжя, Україна
Онищенко Оксана Анатоліївна

Запорізький національний університет

м. Запоріжжся, Україна
Черняк Катерина

Олексіївна

Запорізький національний університет

м. Запоріжжя, Украӥна

Стаття спрямована на систематизацію основних підходів до визначення поняття складського господарства. Проаналізовано сучасні підходи до управління складською логістикою та визначено основні переваги та недоліки їх використання в логістичній системі підприємства. У статті розкрито теоретичні аспекти складської логістики та проаналізовані існуючі підходи до управління складською логістикою сучасних підприємств. Досліджено механізм управління логістикою складу та запропоновано шляхи підвищення його ефективності. Методологія: використовувалися загальнонаукові теоретичні та емпіричні методи дослідження, такі як: аналіз та узагальнення, методи спостереження та порівняння, аналітичні, групування даних. Обгрунтовано актуальність та доцільність модифікації складів на українських підприємствах. Актуальність статті полягає у необхідності залучення вітчизняних підприємств до якісно нової системи економічних відносин та механізмів конкурентних відносин сучасного ринку, а також у нагальній необхідності адаптації суб'єктів господарювання до невизначеності з метою вдосконалення стратегій організації управління, включаючи складську логістику. Практична цінність результатів досліджень полягає в тому, що пропозиції та рекомендації щодо вдосконалення процесу управління логістикою складів, визначені у статті, можуть бути використані підприємствами з метою впровадження сучасних інноваційних підходів до підвищення якості логістичних процесів. Крім того, реалізація запропонованих положень значно знизить матеріально-технічні витрати підприємства та оптимізує діяльність будь-якого виробничого підприємства.

Ключові слова: склад, збереження якості товару, логістика складування, матеріальні запаси, складське приміщення, мінімізація витрат, оптимізація логістичних процесів, сучасні логістичні підходи.

\section{СОВРЕМЕННЫЕ ПОДХОДЫ К УПРАВЛЕНИЮ СКЛАДСКОЙ ЛОГИСТИКОЙ}

Шишкин Виктор

Александрович

Запорожский национальньій университет

2. Запорожье, Украина
Онищенко Оксана

Анатольевна

Запорожский национальный университет

2. Запорожье, Украина
Черняк Екатерина

Алексеевна

Запорожский национальный университет

2. Запорожье, Украина

Статья направлена на систематизацию основных подходов к определению понятия складского хозяйства. Проанализированы современные подходы к управлению складской логистикой и определены основные преимущества и недостатки их использования в логистической системе предприятия. В статье раскрыты теоретические аспекты складской логистики и проанализированы существующие подходы к управлению складской логистикой 
Shyshkin, V., Onyshchenko, O. and Cherniak, K. (2020), "Modern approaches to warehouse logistics management", Management and entrepreneurship: trends of development, Vol. 2, Issue 12, pp. 105-117, available at: https://doi.org/10.26661/2522-1566/2020-2/12-08

современных предприятий. Исследован механизм управления логистикой склада и предложены пути повышения его эффективности. Методология: использовались общенаучные теоретические и эмпирические методы исследования, такие как: анализ и обобщение, методы наблюдения и сравнения, аналитические, группировка данных. Обоснована актуальность и целесообразность модификации складов на украинских предприятиях. Актуальность статьи заключается в необходимости привлечения отечественных предприятий к качественно новой системе экономических отношений и механизмам конкурентных отношений современного рынка, а также в настоятельной необходимости адаптации субъектов хозяйствования $\kappa$ неопределенности в целях совершенствования стратегий организации управления, включая складскую логистику. Практическая ценность результатов исследований заключается в том, что предложения и рекомендации по совершенствованию процесса управления логистикой складов, определенные в статье, могут быть использованы предприятиями с целью внедрения современных инновационных подходов для повышения качества логистических процессов. Кроме того, реализация предложенных рекомендаций значительно снизит материальнотехнические затраты предприятий и оптимизирует деятельность любого производственного предприятия.

Ключевые слова: склад, сохранение качества товара, логистика складирования, материальные запасы, складское помещение, минимизация затрат, оптимизация логистических процессов, современные логистические подходы. 